\title{
Procreative Beneficence, Obligation, and Eugenics
}

\author{
ROBERT SPARROW ${ }^{1}$
}

\begin{abstract}
The argument of Julian Savulescu's 2001 paper, "Procreative Beneficence: Why We Should Select the Best Children" is flawed in a number of respects. Savulescu confuses reasons with obligations and equivocates between the claim that parents have some reason to want the best for their children and the more radical claim that they are morally obligated to attempt to produce the best child possible. Savulescu offers a prima facie implausible account of parental obligation, as even the best parents typically fail to do everything they think would be best for their children let alone everything that is in fact best for their children. The profound philosophical difficulties which beset the attempt to formulate a plausible account of the best human life constitute a further independent reason to resile from Savulescu's conclusion. Savulescu's argument also requires parents to become complicit with racist and homophobic (and other forms of) oppression, which is yet another reason to reject it. Removing the equivocation from Savulescu's argument allows us to see that the assertion of an obligation to choose the "best child" has much more in common with the "old" eugenics than Savulescu acknowledges.
\end{abstract}

\section{Introduction}

Sometimes a paper becomes much cited in the literature because it says something that everyone wants someone else to say. Papers of this sort typically involve extreme positions, logical possibilities that more moderate authors are reluctant to adopt. Such papers often appear to be radical by virtue of promoting views that up to that point have been thought to be absurd. They receive attention because they offer a convenient target for criticism, or because they allow other authors to cite an authority for a position they are unwilling, or unable, to defend themselves. Unfortunately, the price of this sort of fame is sometimes philosophical rigour.

I want to argue that Julian Savulescu's 2001 paper, "Procreative Beneficence: Why We Should Select the Best Children", is precisely a paper of this sort. ${ }^{2}$ It is oft-cited in the bioethical literature because it apparently represents a clear statement of a position in favour of enhancing human beings that has been a possibility in discussions about the ethics of genetic selection ever since pre-implantation genetic diagnosis (PGD) appeared on the technological horizon. ${ }^{3}$ It appears to present a radical view by not only endorsing the use of PGD for enhancement but explicitly advocating it. Savulescu has done little to discourage this impression when he has presented his views in the popular press. ${ }^{4}$

Unfortunately, Savulescu's argument is flawed in a number of respects. As I explore in Section I, Savulescu's formulation of the obligation of procreative beneficence, and

Genomics, Society and Policy, Vol.3, No.3 (2007) ISSN: 1746-5354

(C) ESRC Genomics Network. 
his account of its force, both suffer significantly from an equivocation about the nature of this obligation. Savulescu confuses reasons with obligations and moves between the claim that parents have some reason to want the best for their children and the more radical claim that they are morally obligated to attempt to produce the best child possible. It is trivially true that if parents believe an embryo has some feature that will benefit it then they have a reason to choose this embryo. However, it does not follow from this-and is in fact highly unlikely - that parents do something wrong if they do not select the best child possible. By moving back and forth between these two claims, Savulescu is able to appear to be defending a radical thesis without adequately acknowledging the profoundly counter-intuitive and dangerous implications of his arguments. In Section II, I point out that the requirements of procreative beneficence, properly understood, are in any case much too demanding, such that very few, if any, parents live up to them. Not only would an obligation to maximise their children's life prospects leave no room for parents' own projects, determining what "the best life" consists in is extremely difficult and perhaps even impossible, as I investigate in Section III. Furthermore, as I discuss in Section IV and as Savulescu appears to concede, the demands of procreative beneficence require parents to become complicit in injustice in societies where the opportunities available to children are shaped by sexism, racism, or other forms of systemic oppression. This is a further reason to be cautious about postulating an obligation to have the "best" child. Finally, I argue in Section V that removing the equivocation from Savulescu's argument allows us to see that the assertion of an obligation to choose the best child has much more in common with the "old" eugenics than Savulescu acknowledges. The notoriety that Savulescu's argument has achieved is deserved, not because the position he advocates is radical or new but because it is all too familiar.

\section{Reasons and obligations}

Savulescu's paper addresses the ethics of pre-implantation genetic diagnosis. The principle of "procreative beneficence", which he advances, holds that,

Couples (or single reproducers) should select the child, of the possible children they could have, who is expected to have the best life, or at least as good a life as the others, based on the relevant, available information. ${ }^{5}$

At first sight, this appears to be a straightforward and strong claim about the obligations of parents. Moreover, what the parents are obligated to do appears to be independent of their ideas about it; the ground of this obligation is most naturally thought of as founded in a concern for the life prospects of the future child. Finally, because they are obligated to choose the best child, it is wrong for them to do anything else. Thus - to choose a contemporary example much discussed by bioethicists - it would appear that it is wrong for Deaf parents to choose an embryo to implant on the grounds that it has a genetic predisposition to deafness. 
Yet Savulescu nowhere states that parents do something wrong if they choose anything other than the "best child" and indeed, in a subsequent paper, goes to some effort to argue that parents should be allowed to do so. ${ }^{6}$ As I discuss further below, there is no contradiction involved in arguing that people are doing something wrong and that they should nonetheless be allowed to do it. What is puzzling, however, is how swiftly Savulescu moves to defending the rights of Deaf parents to choose deaf children and how little attention he pays to the possibility that his conclusions about parents' obligations are relevant to the debate about this issue.

One of the reasons Savulescu seems to be reluctant to conclude that "sub-optimal" choices are wrong is because the choices we are considering do not harm or benefit any identifiable individual. If parents fail to choose the best child, the child they do choose is not thereby any worse off, as this child would not have existed except for their parents' choice to bring it into the world. ${ }^{7}$ Parents who fail to do what's best for their children are therefore engaged in "harmless wrongdoing". 8

What is difficult to understand now is where the putative obligation to select the best child comes from. Savulescu's answer to this question seems to be that it is internal to the parents' own desire set. ${ }^{9}$ That is, parents have "reason to choose" the best embryo because it has features that they already recognise as being valuable..$^{10}$ Insofar as parents are motivated by concern for the well-being of their future child in selecting against genetic conditions leading to impairments, they have reason to select in favour of other genes, including those for above-species-normal capacities, which also serve well-being. Rationality requires that they maximise goods they already desire. ${ }^{11}$

However, there are at least three problems with understanding the foundations of procreative beneficence in this way.

First, this way of understanding the source of any parental obligation actually fails to establish any reliable conclusion about what parents "should" do. Parents have reason to choose the embryo that they think will have the best life possible, but this will hardly be news to them. Moreover, parents may also have other reasons that have force for them when choosing amongst embryos. For instance, they may wish to leave matters open to chance, or to avoid becoming involved in human enhancement, or to select a particular type of child for reasons which do not relate to its life prospects. Qua reasons, the reasons that Savulescu identifies, concerning the future well-being of the child, have no more force than any other reasons that parents may have for making their decisions. An argument for procreative beneficence founded only in the parents' own reasons therefore cannot support any robust generalisations about what they should do. Nor, as I discuss further below, can it grant its conclusions the resilience against countervailing reasons which is characteristic of moral obligation.

Second, this account fails to properly locate the origins of the normative imperative it postulates. Obligations are limits on our range of ethically acceptable actions that are imposed by the moral demands of others. Even where obligations are not owed

Genomics, Society and Policy, Vol.3, No.3 (2007) ISSN: 1746-5354

(C) ESRC Genomics Network. 
directly to particular persons, we can usually identify those parties whose interests are the source of the obligation.

It is true that when considering choices about which embryos we select to bring into the world we cannot straightforwardly claim that those children who we do decide to bring into existence are harmed by comparison to those we do not. ${ }^{12}$ Nevertheless, it is clear that any obligations we have in this instance must in some sense arise from a concern for the interests of "the child"-if not the particular child who will be born as a result of the decision. ${ }^{13}$ Just how to describe and evaluate the harm or wrong done when parents fail to be adequately concerned for life prospects of the children they do bring into the world is a profound philosophical problem. ${ }^{14}$ However, we should not let our puzzlement at this dilemma distract us from the obvious truth that if we do have obligations in such instances it is because the results of our decisions will be sentient entities who will have to live with them.

Acknowledging that any plausible parental ethic must be based on a concern for the interests of children helps us to understand the third difficulty with Savulescu's account, which is its failure to capture adequately the force of an obligation, which is what Savulescu claims to be defending elsewhere in his paper. ${ }^{15}$ Notice that as Savulescu grounds the putative obligations of parents in their own desire set there is nothing in particular that parents should do. They can change the content of the obligation of procreative beneficence by changing their desires. Yet an obligation on parents to do whatever they think is right is extremely implausible. The interests of children are not served by their parents doing whatever they think is best. ${ }^{16}$ They are served by parents doing what actually is best for their children, where this is (largely) independent of what the parents happen to think about it. ${ }^{17}$ An obligation to have the best child would require parents to do something which is independent of their desire to do it, and would retain its force even in the face of substantial (non-moral) reasons the parents might have to pursue another course of action. ${ }^{18}$

Savulescu is therefore confusing reason and obligation at the very foundations of his account. Tellingly, this ambiguity is present in the example that Savulescu chooses to illustrate the nature of the obligation he is postulating. He claims that the "should" in "parents should choose the best child possible" is the same as the "should" in the proposition that "you should stop smoking". ${ }^{19}$ This example obscures more than it illuminates as the "should" in this latter phrase is itself indeterminate between a requirement of practical rationality and a moral claim. In one sense, smokers ought to give up smoking if they want to avoid cancer. This is a hypothetical imperative and has no force for the smoker who values the pleasures of nicotine above those of a long life. Moreover, once the smoker has explained his or her values to us, we must acknowledge that in fact they should not stop smoking. However, on another stronger reading, the "should" in "you should stop smoking" is a normative or moral claim. This is in fact the proper form for modelling obligation. This imperative holds regardless of the smoker's set of preferences and is (presumably) founded in a judgement that self-harm is morally wrong or that it is not possible to smoke without subjecting others to an unacceptable risk from passive smoking. We can rightly

Genomics, Society and Policy, Vol.3, No.3 (2007) ISSN: 1746-5354

(C) ESRC Genomics Network. 
continue to insist that the smoker should stop smoking even in the face of their confession that they are happy to risk cancer in the pursuit of pleasure. It also follows from this second sense of the claim that the smoker should stop smoking that the smoker is wrong to smoke, does a bad thing if they smoke, and also that we have some prima facie justification for taking action to prevent them from smoking.

The distinction between these two different sorts of claims is blurred in the case of the smoker because of the pervasive moralism that has grown up around smoking in the English-speaking world in the last two decades. As a result we now tend to feel that smokers are not just individuals with a different set of preferences in relation to pleasure and health but that they are bad people. This blurring of the line between a matter of taste and a moral failing in the familiar case upon which he models his account obscures the same equivocation in Savulescu's argument.

If an obligation exists to select the best child, this is a moral imperative and not a mere reason. Moreover, which is the "best" child is independent of parents' ideas about it. Of course, it is not impossible to hold simultaneously that people are morally obligated to do $\mathrm{X}$ and that the state should not force them to do $\mathrm{X}$. This is a traditional liberal combination of claims; typically, it reflects the existence of other competing obligations on us to respect the choices of others and/or the existence of forceful pragmatic concerns about the dangers of the use of state power to enforce morality. Savulescu is therefore not committed by his argument that parents are obligated to choose the best child to the conclusion that parents should be required by law to do so. However, he is committed to the claim that parents who fail to choose the best child are doing the wrong thing and also to the claim that in many circumstances we should tell them they are doing the wrong thing and try to persuade them to do otherwise. ${ }^{20}$ Moreover, because "best" is a maximising notion, in an ideal world where people met their obligations, everyone would choose the same kind of children. That this is the logical outcome of Savulescu's argument suggests that there are more similarities between his position and the "old" eugenics of the 1930s than Savulescu acknowledges.

\section{Procreative beneficence and parenting}

Before we move to consider the implications of Savulescu's thesis, properly understood, in Sections IV and V, it is worth noting that it is, prima facie, an implausible account of parental obligations. Even the best parents typically fail to do everything they think would be best for their children let alone everything that is in fact best for their children. Parents often not unreasonably choose to put their own interests ahead of those of their children in relation to at least some of their decisions. In order to secure the best life possible for their children, parents would be obligated to spend all of their disposable income on their children's education and upbringing. In order to maximise the opportunities available to their children, parents would have to teach them as many of the "world" languages (English, Mandarin, Hindi, and Spanish) as possible. These are impossibly high expectations of parents and we do not criticise parents who fail to meet them. ${ }^{21}$

Genomics, Society and Policy, Vol.3, No.3 (2007) ISSN: 1746-5354

(C) ESRC Genomics Network. 
Perhaps this reflects the fact that in ordinary circumstances parents are responsible for the well-being of particular children rather than a choice between children. However, it is extremely difficult to see how this fact should make a difference here. If anything, one would think that if there are obligations to maximise the well-being of children they would be most apparent in cases like these, where it is possible to identify a child that is harmed by the failure to live up to this obligation. The absence of an obligation to maximise the well-being of existing children suggests that no such obligation exists when we are choosing between children. Moreover, even when it comes to familiar reproductive decisions which determine who will be born, while we recognise some obligation on parents to be concerned for the future well being of the child who will be born, this falls well short of an obligation to try to maximise that well-being. Thus, for instance, we do not demand of parents that they should delay having children until they can offer them the best possible circumstances into which to be born. There is little evidence in our ordinary child rearing and reproductive practices for any maximising obligation of the type Savulescu proposes.

\section{The best of "the best"?}

It is perhaps fortunate that parents do not typically feel obligated to produce "the best child possible" because, as I argue in this Section, it is extremely difficult to determine what the "best child" consists in. Our ordinary practices of parenting sidestep the difficult philosophical problems that haunt Savulescu's account.

Savulescu allows that there are four obvious candidates for a criterion by which we should judge which child is likely to have the best life. They are hedonism, a desirefulfilment theory, an objective list theory, and a concern for a maximally open future. ${ }^{22}$ He suggests that they all support decisions to prefer a familiar and plausible list of character traits in a child. ${ }^{23}$ On closer investigation, the first two lead directly to implausible conclusions, the third, while plausible, is extremely and inherently controversial, while the fourth is both controversial and ultimately implausible.

Hedonism, a concern for the amount of pleasure the child will experience, is right from the start an implausible way of evaluating which child is likely to have a better life because of the well-known problems with hedonism as a philosophy of life more generally. A good life consists in more than a merely pleasurable life. The prospect of technologies of genetic control actually draws attention to the inadequacies of the narrow account of well-being offered by hedonism. If our concern were to produce a child who would experience the most pleasure it seems that we should be concerned solely with the structure of their nervous system and their levels of relevant neurotransmitters. We should choose the child which will have the highest base levels of serotonin, for instance. If we had access to a mature recombinant DNA technology for human beings then we should engineer our children so that they had a brain chemistry such that they lived in permanent ecstasy. However, no sensible critic would think that we are obligated to pursue this end when it comes to choosing our children.

Genomics, Society and Policy, Vol.3, No.3 (2007) ISSN: 1746-5354

(C) ESRC Genomics Network. 
A "desire-fulfilment" theory combines a concern for the child's well-being with a recognition of pluralism by allowing that well-being consists in the satisfaction of an individual's desires whatever they may be. However, here too the prospect of control over the genetic influences on phenotype actually serves to illustrate the limitations of such a theory as an account of well-being. To a certain degree we can perhaps, as Savulescu suggests, act so as to improve the chances of a child satisfying its desires by improving its capacities. ${ }^{24}$ This will be more practicable if we can identify certain general-purpose capacities, such as intelligence, health, beauty, and longevity, which allow people to achieve their goals regardless of the nature of these goals. ${ }^{25}$ However, there is inevitably a limit on how much we can ensure that our children's desires will be satisfied due to the fact that this depends ultimately on the state of the world, over which we have little control. This upper limit on the success of enhancement might serve only as a timely reminder of the role played by fate in a human life but for the fact that there is another way we can try to ensure that our children's desires are fulfilled-by changing the nature of these desires. We can greatly improve the chances that our children's preferences will be satisfied by lowering their preferences. Children who will grow up to have easily satisfied preferences are more likely to experience the satisfaction of those preferences and thus-by this account-have better lives. We should therefore as far as possible attempt to produce easygoing, easily pleased children. If we can find genes which depress ambition, or curiosity, for instance, then we should select in favour of these genes. ${ }^{26}$ Again, this strikingly counter-intuitive result tells against the idea that a good life consists only in the satisfaction of desires.

The vulnerability of desire-fulfilment theories to the possibility of revising our desires downwards can be mitigated by requiring that desires be subject to a test of idealisation or reflective rational endorsement. It may, in fact, be harder to describe or defend such a test when the desires we are considering are the future desires of a person who does not yet exist. However, the main problem with this move is that in order to identify those desires we should be concerned to fulfil, we need to know which things it is important to desire. That is, we need to move towards an "objective list" theory of well-being.

In contrast to the evaluative schemas discussed above, an objective list theory does not lead to absurd conclusions in circumstances where we have an infinite power to manipulate the genetics of our children. If a good life consists in a life which includes objective goods such as love, wisdom, beauty, happiness, dignity, etc, then it is unlikely that we can directly engineer success in life. ${ }^{27}$ However, it may well be possible to choose children who are more likely to succeed in the pursuit of these goods.

What is far less clear though is whether we can on this account give any content to the idea of the best life possible. Any plausible account of objective goods will include goods of widely different natures, which are probably incommensurable. Any account of the relative merits of these competing goods and the sorts of trade-offs we should

Genomics, Society and Policy, Vol.3, No.3 (2007) ISSN: 1746-5354

(C) ESRC Genomics Network. 
make between them will be a thousand times more controversial than this list of goods itself. If goods are incommensurable it may be impossible to rank competing lists of goods. The attempt to identify the best life using an objective list theory of the good is therefore fraught with difficulty; it is at best extremely controversial, if not ultimately impossible.

The final means of evaluating what the best life consists in attempts to avoid the difficulties that have beset those above by assessing the number of options available to future children rather than their content. The best possible child is the child with the most "open future". ${ }^{28}$ However, the idea of a maximally open future is also beset by difficulties. It is far from obvious that competing opportunities, or sets of opportunities, are commeasurable. A child may have the genetics to be a world-class jockey or a world-class basketball player, for instance, but not both. This problematises the comparison between futures necessary to decide which are more open. Moreover, an obsession with the openness of futures neglects the ways in which the existence of more choices can actually lower well-being by increasing the costs of choice or by hindering our ability to "bind" ourselves to difficult projects. ${ }^{29}$ Finally, it is clear that not all opportunities are in fact valuable. Where opportunities are opportunities to pursue projects which lower well-being (eg, self harm), or which themselves would close off other future opportunities (eg, addiction), the presence of these opportunities may detract from rather than serve well-being. This means that if we are concerned for the well-being of children then on any plausible account thereof, we should actually work to close off rather than keep open some options. Which options we should try to close off depends on what is good-or in this case, bad-in life. In order to be plausible, then, the idea of an open future relies crucially on an underlying objective list account of the good and consequently inherits the difficulties noted above.

According to the most plausible account of the nature of well-being then - an objective list account-we do have some reason to select against embryos with genetics likely to lead to impairments and also in favour of embryos with genes for enhanced capacities, should we become capable of identifying the presence of such genes. However, on this account any notion of a "best child" is extremely controversial, if not incoherent. These difficulties with formulating an interpretation of the requirement of procreative beneficience which is both plausible and action guiding constitute a further independent reason to resile from Savulescu's conclusion. $^{30}$

\section{The real world of procreative beneficence}

If the philosophical problems involved in identifying the "best child" are daunting, the pursuit of this goal seems likely to lead to even more unpalatable consequences in a world in which the life prospects of children are substantially determined by the existing, often unjust, social order. That Savulescu's argument requires parents to become complicit with racist and homophobic (and other forms of) oppression is yet another reason to reject it.

Genomics, Society and Policy, Vol.3, No.3 (2007) ISSN: 1746-5354

(C) ESRC Genomics Network. 
To give him due, Savulescu does not shy from acknowledging that his account appears to lead to repugnant conclusions when parents are situated in sexist or racist societies. ${ }^{31}$ In many societies, it is clear that children who are born members of an oppressed race or sex have lives that are harder and contain fewer valuable opportunities than those of children who grow up to become members of the dominant groups. It follows straightforwardly from Savulescu's argument that in such societies parents are obligated to choose children who will be members of the dominant groups, if possible. ${ }^{32}$

Savulescu attempts to mitigate the impact of this conclusion in three ways. He argues in relation to sex selection that if it were to lead to an imbalance in the ratio of the sexes in a society, this dynamic would eventually become self-correcting at a point at which male children can expect to experience decreased well-being by virtue of the scarcity of prospective mates. ${ }^{33} \mathrm{He}$ also insists that it is wrong to censure the reproductive choices of parents on the grounds of their implications for society at large because to do so would be to revisit an "old" eugenic concern for the health of the "race" —or at least society. Instead, he argues, the appropriate response to the existence of racism and other forms of discrimination is social and institutional change. ${ }^{34}$

Savulescu's first response perhaps works for sex but has absolutely no force in the case of hypothetical selection on the basis of genes for skin colour or sexual preference. Even in the case of sex I am inclined to agree with Immaculada de MeloMartin that the aggregative effects of the choices of parents who are guided by a concern for procreative beneficence may prevent this "corrective" mechanism from operating effectively. ${ }^{35}$ That is, when confronted with a choice about the sex of their future child, in the context of a sexist society, it will be extremely difficult for parents to know what the future ratio of the sexes will be. In the absence of reliable information about such it may be rational for parents to choose to have male children because that way they can at least be certain that their child will be free of the pernicious direct influences of existing sexism.

However, in a society in which parents are selecting in favour of children with fair skin, as a result of the limited opportunities available to dark-skinned children due to societal racism, there is no reason at all to expect that at some point in this process the life prospects of fair-skinned individuals will decrease, nor is there any reason to believe that the effects of racism will reverse so that dark-skinned children can be expected to achieve higher levels of well-being than fair-skinned children. Members of a racial minority do not acquire more bargaining power or privileges as the minority of which they are members grows smaller nor can we reliably expect that levels of racist hostility will decline as minorities disappear. Indeed, in both regards it seems likely that the prospects for well-being for members of identifiable racial minorities are likely to worsen the more parents there are who choose to avoid having children who can be identified as members of those minorities. ${ }^{36}$ Savulescu therefore cannot avoid the conclusion that if technologies of genetic selection for racial markers ever become available, parents in racist societies would be obligated to select against

Genomics, Society and Policy, Vol.3, No.3 (2007) ISSN: 1746-5354

(C) ESRC Genomics Network. 
children who might be identified as members of the oppressed race. As a consequence, if parents do as he suggests, the wildest dreams of race supremacists would be realised and racial minorities would disappear in one or two generations.

Similarly, if a genetic basis for same-sex attractedness can be found, Savulescu's arguments imply that in societies where those who are same-sex attracted are discriminated against and suffer reduced opportunities parents should select against these genes. Again, I can see no reason to expect that life prospects would diminish for heterosexuals as the relative number of homosexuals in the community decreased. Savulescu appears to have no recourse other than to admit that homosexuals would disappear from most societies if a genetic basis for same-sex attractedness can be found and his arguments are accepted.

Savulescu's second response raises difficult questions about the obligations of both parents and philosophers when confronted by systemic injustice.

To begin with, it is misleading to characterise the criticism Savulescu is responding to as the demand that parents should choose children in the service of social justice. ${ }^{37}$ By presenting critics of his account as threats to reproductive liberty, Savulescu is able to portray himself as the brave defender of reproductive liberty against the evil of political correctness applied to procreation. If critics were postulating an obligation to take issues of racial or gender justice into account when planning families, they would in fact be doing no more than Savulescu himself when he insists that parents should be conscious of such injustice in order to protect their children from its effects. However, more importantly, as Savulescu's own commitments demonstrate, talk of reproductive liberty in this context is a red herring. The issue here is not whether parents should be forced to have children of one sort or the other, but whether they are obligated to do so.

The real question here then is whether the likely social impact of Savulescu's account counts against an obligation to maximise one's child's well-being. This is another point where the equivocation between reason and obligation in Savulescu's account obscures the full implications of his conclusions. Savulescu states that "we should allow selection for non-disease genes... even if this maintains or increases social inequality" implying that his account only identifies reasons why parents might want to select particular sorts of children. ${ }^{38}$ Yet he is being modest here about the significance of his argument which, if it succeeds at all, establishes an obligation to choose the best child. ${ }^{39}$ Savulescu's account demands that parents should become complicit with sexist, racist, and homophobic oppression in what is arguably one of the most meaningful and personal choices they are likely ever to make.

It counts against a theory of obligation if the obligations it postulates would place people under psychological pressures which it is unreasonable to expect them to sustain. This is clearly true of procreative beneficence as promulgated by Savulescu, and his account is less plausible because of it. 
More controversially, it should also, I think, count against a theory of obligation if a world in which people met their obligations would be substantially the poorer for it. We must be careful here, as there is in fact no guarantee that different parties will not sometimes each be obligated to act in such a way as will produce a poor outcome, or even a moral tragedy. Nevertheless, if it is obvious that if most people met a putative obligation it would threaten other important goods, we have reason to reconsider its status as obligation. Insofar as we think that diversity within the community is a significant good we therefore have reason to question the obligation of procreative beneficence.

Moreover, while the obligation that Savulescu postulates is not in itself a limit on the reproductive liberty of parents, the aggregate effect of other people meeting this obligation may well impact significantly on parents' freedom to make particular reproductive choices. ${ }^{40}$ For instance, if the number of children who are born deaf should decrease markedly as a result of the widespread use of a screening technology then the chances of those children who are born deaf having access to a flourishing Deaf culture, or to social programs designed to allow them to participate as full members of the wider community, will be greatly reduced. This will in turn greatly reduce the liberty of parents to choose a deaf child or-more plausibly - to refuse to screen for deafness, without having to anticipate excessive social and economic burdens. To the extent that we value the freedom of parents to make a wide range of choices about their children, we have reason to be suspicious of an obligation to choose the best children.

Finally, even if Savulescu is correct that the social impacts of his argument do not count against the existence of an obligation to select "the best child" they might nevertheless provide grounds for criticising his enthusiasm for publicising this obligation. There are times when the right thing to do and the right thing to tell other people to do come apart. ${ }^{41}$ If we judge the consequences of the widespread pursuit of procreative beneficence to be bad enough we may feel that we should not accelerate this process by reminding parents of their obligations.

Savulescu's final response to the criticism that the obligation he proposes would lead to repugnant consequences is to insist that the appropriate response to discrimination and injustice is not to criticise the reproductive choices of parents but to establish social programmes to combat them. ${ }^{42}$ Again, this is to confuse criticism of Savulescu's own account of the obligations of parents with criticism of parents' choices. However, more importantly, it is in any case difficult to see upon what grounds Savulescu can justify this claim. Social programmes to combat racism or other forms of discrimination will impose costs on the liberty of other citizens in the form of extra burdens of taxation to fund them. These burdens would be reduced if we encouraged prospective parents to meet their supposed obligations thus diminishing the presence of minorities within the community. ${ }^{43}$ It is far from clear what reasons Savulescu could give to explain his preference for imposing costs on third parties rather than requiring parents to do the right thing. 
It seems then that an obligation to choose the best child will, if widely realised, inevitably lead to further discrimination against minorities and oppressed groups given that the life prospects of children will be largely determined by existing social relations. Does this mean that parents have an obligation to take questions of social justice and inter-group relations into account and choose in favour of children who might improve the relative position of oppressed groups? This seems extremely unlikely; such an obligation would also require parents to revise their most intimate and personal decisions to respond to external political circumstances and thus would make similarly psychologically implausible demands on them. Yet it is possible to be critical of an account of parental obligations that asserts an obligation to become complicit with injustice without counter-posing one's own preferred obligation. The proper conclusion here is, I think, that the injustice of systemic injustice serves to remove the obligation to take those particular environmental influences into account when considering the future well-being of children. We should not criticise the choices that parents might make and in particular we should not demand of them that they should choose children who will be members of majority groups. This leaves the question of the appropriate policy response to the likely impacts of technologies of genetic selection, and in particular their aggregative effects, unresolved: this is a larger question than I can hope to settle here. However, what I hope that I have shown is that Savulescu's account can in this regard itself serve only as an illustration of the disturbing implications of the demand that parents should select only the best children.

\section{Procreative beneficence and eugenics}

Although Savulescu clearly wants to be associated with the "new" eugenics ${ }^{44}$ and its rhetoric of freedom and individual choice, ${ }^{45}$ by postulating an obligation to pursue a maximising notion (and given some plausible assumptions about the limits of our capacity to predict the environment in which children will grow up) he is arguably committed to the conclusion that there is only one sort of child that should be brought into the world. "Best" is not an idea which allows room for pluralism. ${ }^{47}$ Thus if we could identify an embryo which had the best possible genetics, it appears that all prospective parents would be obligated to implant clones of this embryo. ${ }^{48}$ This vision of a world of identical "perfect babies" looks disturbingly similar to that which motivated the "old eugenics" of the 1930s.

Savulescu denies that he is committed to any morally problematic form of eugenics because of his insistence on the reproductive freedom of parents. Indeed, he insists that parents should be free to determine the sort of children they bring into the world even when this involves clear violations of procreative beneficence. ${ }^{49}$ Is Savulescu's notional opposition to any role for the state in enforcing the obligations of procreative beneficence enough to disassociate him from the moral opprobrium that surrounds the eugenics of the past? This depends on our analysis of the evils of the old eugenics. I believe that in their eagerness to rehabilitate (" the new") eugenics, bioethicists have failed to properly locate at least part of what people object to in the idea that we should try to have only "the best" children. While the worst evils of the old eugenics were carried out by the state in the pursuit of eugenic goals it seems to me that what

Genomics, Society and Policy, Vol.3, No.3 (2007) ISSN: 1746-5354

(C) ESRC Genomics Network. 
people object to in past eugenics programs is not just the means used but also the goal. There is something fundamentally misguided in the belief that one can determine which are the best human beings. Beyond a reasonable concern that people should have access to a normal range of goods, it is a morally reprehensible arrogance to try to stand in judgement over human lives. This essentially virtue-ethical critique of eugenic goals arguably has the resources to distinguish between a therapeutic concern for health and more substantive conceptions of what makes better human beings. Savulescu's account of procreative beneficence, with its strongly maximising notion of "the best" child clearly falls on the wrong side of this line.

Moreover, while it does not necessarily follow that the state is justified in coercing parents simply because they are doing something wrong, the argument does at least get off the ground. That is, while there is a strong presumption that a liberal state will not act if there is no wrong being done, or merely on the grounds that some citizens feel a wrong is being done, if a moral obligation is being flaunted this may form the beginning of an argument to the conclusion that the state should intervene to rectify the situation. The argument for state intervention becomes stronger the more important the obligation is and the more third parties there are who are harmed by others' failure to live up to their obligations.

On both these grounds, it seems as though there are good prima facie reasons for the state to enforce the obligation of procreative beneficence. Once we understand the origins of the obligation of procreative beneficence as founded in a concern for the well-being of future children rather than the preferences of the parents, then failures of procreative beneficence appear to be significant moral wrongs. It is true that these failures do not lead to harms to particular children; they may, however, involve grave wrongs. ${ }^{50}$

Moreover, even if we deny that the impact of failures of procreative beneficence on the children who are born as a result of them constitutes harm of the sort that justifies state intervention, failures of procreative beneficence can lead to significant harms to other third parties. When parents fail to choose the best children they are imposing significant burdens on the rest of society. This is obvious if parents choose children with impairments and the rest of the community is then expected to fund therapeutic and/or social programmes to mitigate the effects of any disability which might result. ${ }^{51}$ What is less obvious but equally true is that parents who fail to choose maximally-enhanced children are also generating negative externalities for the rest of the community. If there are advantages in being an "enhanced" human being, there must by comparison be costs involved in being a normal human being. Some of these costs will inevitably be borne by the community, which must devote resources to facilitating the pursuit of goals that enhanced beings would reach more easily. Moreover, when parents impose these costs they do so in the course of doing something which is already independently morally wrong. This lends further weight to the claim that these impacts are not merely costs but harms which may serve as the basis of an argument for state action to prevent them. 
Savulescu is correct to note that a concern for individual freedom in general and reproductive liberty in particular provides a significant counterweight to any argument that the state should enforce eugenic goals. ${ }^{52}$ However, what he fails to acknowledge is that his own account of procreative beneficence provides no support for these concerns at the same time as it provides a great deal of support for an argument that the state would be justified in requiring that parents should meet the obligation he proposes.

\section{Conclusion}

On a charitable interpretation, Savulescu's paper has advanced the debate about the ethics of PGD by bringing the eugenic commitments of the "new eugenics" into the open. It is unfortunate that it has also muddied the waters by equivocating between a claim about reasons parents may have to choose the best child and a claim about what they are obligated to do in an area where this distinction is absolutely necessary in order to make it possible to properly evaluate very different arguments. Moreover, Savulescu's own conclusions are clearly mistaken. Parents are not obligated to have the best child possible. They are, as others have argued, obligated to choose a child that will have "a life worth living". 53 They may be obligated to choose one who is likely to have a life which will include a certain basic minimum of objective goods or some acceptable level of "open future". ${ }^{4}$ These obligations leave a great deal of freedom to the parents to decide what sort of child they wish to bring into the world. An obligation to maximise any value, to choose only "the best", would entirely determine parents' choices, render them subject to moral censure if they fail to make this choice, and open the door to proposals that they should be legally required to make it. There may well be reasons to ignore the therapy/enhancement distinction and to "improve" our children by selecting for non-disease traits, as Savulescu suggests. However, any argument to this conclusion will require an account of parental obligation and of the nature of well-being which is both more rigorous and more nuanced than that which Savulescu provides.

\section{Acknowledgements}

I would like to thank Jacqui Broad, Debra Dudek, Toby Handfield, and Justin Oakley for helpful comments and discussion over the course of the development of this paper.

\footnotetext{
${ }^{1}$ Centre for Human Bioethics, Faculty of Arts, Monash University, Australia, \& Centre for Applied Philosophy and Public Ethics, University of Melbourne, Australia Robert.Sparrow@arts.monash.edu.au

${ }^{2}$ J. Savulescu. Procreative Beneficience: Why We Should Select The Best Children. Bioethics 2001; 15(5): 413-426.
}

Genomics, Society and Policy, Vol.3, No.3 (2007) ISSN: 1746-5354

(C) ESRC Genomics Network. 
${ }^{3}$ The ISI Web of Science lists 26 citations as of 20 Jan 2008.

${ }^{4}$ A. Dunn. Create Best Child Possible, As Our Future Depends On It: Bioethicist. Sydney Morning Herald 2004; November 16. Sydney, N.S.W: 5; A. Dunn and T. Noble. Should Science Reshape the Human Race? The Age 2005; June 5. Melbourne, Victoria: Agenda 12-13; J. Miles. How Far Would You Go for the Perfect Baby? How Far Should Society Go in Allowing Genetic Manipulation to Produce Happier, Healthier and Physically Pleasing People? Townsville Bulletin 2005; June 18. Townsville, Queensland: 67; M. Metherell. Bring on the Super Humans. Sydney Morning Herald 2005; June 9. Sydney, N.S.W: 3. J. Savulescu. National Australia Bank Address to National Press Club 2005; June 8. Barton, Canberra, Australia. Available online at http://www.asmr.org.au/media/NPCTRSC05.pdf (accessed July 20, 2006).

${ }^{5}$ Savulescu, op. cit. note 2, p. 415. In fact, the obligation established by procreative beneficence is slightly stronger than this quotation suggests because Savulescu further holds that parents are obligated to use testing technologies and to test for the largest number of conditions possible in order to be able to exercise choice over what sort of child they have (Savulescu, op. cit. note 2, p. 424, and J. Savulescu. In defence of Procreative Beneficence. Journal of Medical Ethics 2007; 33: 284-288 at p. 285).

${ }^{6}$ J. Savulescu. Deaf Lesbians, "Designer Disability", and the Future of Medicine. British Medical Journal 2002; 325: 771-775.

${ }^{7}$ Savulescu, op. cit. note 2, p. 422; J. Glover. 2001. Future People, Disability, and Screening. In Bioethics. J. Harris, ed. Oxford. Oxford University Press: 429-44.

${ }^{8}$ Savulescu, op. cit. note 2, p. 418; Dan Brock. The Non Identity Problem and Genetic Harms - the Case of Wrongful Handicaps. Bioethics 1995; 9(3/4): 269-275.

${ }^{9}$ Savulescu, op. cit. note 2, p. 414 \& p. 416.

${ }^{10}$ Savulescu, op. cit. note 2, pp. 416-17.

${ }^{11}$ Savulescu, op. cit. note 2, p. 416; K. Birch. Beneficence, Determinism And Justice: An Engagement with the Argument for the Genetic Selection of Intelligence. Bioethics 2005; 19(1): 12-28 at p. 14.

${ }^{12}$ Savulescu, op. cit. note 2, p. 422; Glover, op. cit. note 7.

${ }^{13}$ Brock, op. cit. note 8, p. 275. Savulescu himself acknowledges at a number of points (Savulescu, op. cit. note 2 , p. $417 \&$ p. 423 ) that it is the impact of our decisions on the well-being of the child that will be born as a result of our decisions that is at issue here.

${ }^{14}$ Brock op. cit. note 8; C.B. Cohen. "Give Me Children or I Shall Die!” New Reproductive

Technologies and Harm to Children. Hastings Center Report 1996; 26(2): 19-27; J. Feinberg. Wrongful Life and the Counterfactual Element in Harming. Social Philosophy \& Policy 1987; 4(1): 145-78; Glover, op. cit. note 7.; J. McMahan. 2001. Wrongful Life: Paradoxes in the Morality of Causing People to Exist. In Bioethics. J. Harris, ed. Oxford. Oxford University Press: 445-75; D. Parfit. 1984. Reasons and Persons. Oxford. Clarendon Press; B. Steinbock \& R. McClamrock. When Is Birth Unfair to the Child? Hastings Center Report 1994; 24: 15-21; C. Strong. Harming by Conceiving: a Review of Misconceptions and a New Analysis. Journal of Medicine and Philosophy 2005; 30: 491-516.

${ }^{15}$ Savulescu, op. cit. note 2, p. 414 \& p. 425.

${ }^{16}$ A. Buchanan, D.W. Brock, N. Daniels, and D. Wikler. 2000. From Chance to Choice. Cambridge. Cambridge University Press: 164.

${ }^{17}$ The caveat here is intended to acknowledge that parents' ideas about what's best for the child may influence what is actually best for the child in so far as the parents' ideas are likely to impact upon the child's life during the course of its upbringing.

${ }^{18}$ In a recently published paper, Savulescu seems to suggest that various features of embryos (for instance, the absence of genes for heart disease, cancer, or disability) are "objective goods" when he writes of the "badness" of these disease conditions as providing the reason to avoid them (op. cit. note 5 , p. 284). If this is true, it provides a better foundation for the claim that parents are obligated to choose embryos possessing these features. However, equally well, it strengthens the arguments, 
explored below, that parents should be required to have particular sorts of children and therefore exacerbates the eugenic implications of Savulescu's position.

${ }^{19}$ Savulescu, op. cit. note 2, p. 415.

${ }^{20}$ Savulescu, op. cit. note 2, pp. 425-6. The qualification here is intended to allow for the psychologically plausible possibility that in some cases direct criticism will be counter-productive to the goal of getting parents to change their minds.

${ }^{21}$ Buchanan, op. cit. note 16, p. 162.

${ }^{22}$ Savulescu, op. cit. note 2, p. 419-20.

${ }^{23}$ Savulescu, op. cit. note 2, p. 419-21.

${ }^{24}$ Savulescu, op. cit. note 2, p. 420.

${ }^{25}$ N. Agar. 1999. Liberal Eugenics. In Bioethics: An Anthology, H. Kuhse and P. Singer, eds. Oxford. Blackwell: 171-181; Buchanan, op. cit. note 16, pp. 167-9; Savulescu, op. cit. note 5, p. 284-285.

${ }^{26}$ Of course, it is hard to know whether such genes exist, but this is equally true of genes postulated for other character traits such as intelligence, memory, or curiosity, which regularly feature in discussions of human enhancement.

${ }^{27}$ Agar, op. cit. note 25.

${ }^{28}$ J. Feinberg. 1980. The Child's Right to an Open Future. In Whose Child? Children's Rights, Parental Authority, and State Power. W. Aiken and H. LaFollette, eds. Totowa, N.J. Littlefield, Adams \& Co.: 124-53.

${ }^{29}$ G. Dworkin. 1988. Is More Choice Better than Less? In The Theory and Practice of Autonomy. Cambridge. Cambridge University Press: 62-81.

${ }^{30}$ Michael Parker has also recently criticised Savulescu's account of the obligation of procreative beneficence for neglecting the extent to which judgements about the relative merits of lives are controversial, although without explicitly distinguishing between the different possible basis upon which a life might be judged "best" explored here. Parker similarly concludes that, as a result, the principle of procreative beneficence underdetermines choices between possible children and therefore fails to be action guiding. See Michael Parker. The best possible child. Journal of Medical Ethics 2007; 33: 279-283.

${ }^{31}$ Savulescu, op. cit. note 2, p. 413.

${ }^{32}$ Savulescu, op. cit. note 2, pp. 423-4.

${ }^{33}$ Savulescu, op. cit. note 2, p. 424.

${ }^{34}$ Savulescu, op. cit. note 2, p. 424.

${ }^{35}$ I. de Melo-Martin. On Our Obligation to Select the Best Children: A Reply to Savulescu. Bioethics 2004; 18(1): 72-83.

${ }^{36}$ It is also possible that the case of sex is closer to this case than Savulescu's more optimistic projection. That is, it is possible that as the proportion of women in society decreases, the life prospects of individual women will actually get worse rather than better, as the relative lack of women in each social role allows sexism to flourish and the demographic domination of men leads to their political and economic hegemony over women.

${ }^{37}$ Savulescu, op. cit. note 2, p. 424.

${ }^{38}$ Savulescu, op. cit. note 2, p. 413.

${ }^{39}$ Savulescu, op. cit. note 4.

${ }^{40}$ de Melo-Martin, op. cit. note 35.

${ }^{41}$ J.J.C. Smart. 1995. An Outline of a System of Utilitarian Ethics. In Utilitarianism: For and Against. J.J.C. Smart and B. Williams. Cambridge, New York, and Melbourne. Cambridge University Press: 374 at pp. $49-57$.

${ }^{42}$ Savulescu, op. cit. note 2, p. 424. 
${ }^{43}$ Perversely, reducing the number of members of minorities within the community would reduce the total social cost of programs to mitigate the burden of discrimination at the same time as it would increase the level of discrimination experienced by those members of minority groups who remained. ${ }^{44}$ Buchanan et al., op. cit. note 16, p. 9 \& Chapter 2.

${ }^{45}$ Savulescu, op. cit. note 2, pp. 424-25.

${ }^{46}$ If we were able to reliably identify a child's future environment and to identify those genes that would best allow them to flourish in that particular environment, the "best child" might differ across different environments. Indeed, my discussion of the implications of Savulescu's argument for the choices of parents in racist, sexist, or homophobic societies suggested that the "best" child would differ across societies in response to the prevailing bigotry of the time. This presumes, of course, that we can be confident that the child will in fact grow up in that particular society. However, as Nicholas Agar (op cit. note 25) has argued, not only will it ordinarily be extremely difficult to reliably predict a child's future environment, it will also be extremely difficult, if not impossible, to identify genes (or combinations of genes) that will benefit a child only in particular, narrowly defined, environments. This means that, for the most part, the genes that make an embryo likely to become the "best child" will be genes that code for traits that would be likely to benefit the child in (and across) a wide range of environments. An embryo with genes for the largest number of these traits to the highest degree may therefore turn out to be likely to produce the "best child" across all the environments it is reasonable to anticipate. In any case, Savulescu is at least committed to the conclusion that there is only one type of child that should be brought into the world in any given environment.

${ }^{47}$ This is not to deny that what counts as best is extremely controversial and likely to be disputed amongst different sets of parents. However, as argued above, Savulescu's thesis claims that parents must have the (objectively) best child and not merely the child they think is best.

${ }^{48}$ A further complexity here is that this would deny parents any particular genetic relationship with their child. It might be argued that this is unreasonable and that parents should only be expected to choose the best child from amongst embryos of which they were the genetic parents. However, it is unclear whether and why the parents' desires for genetic offspring should outweigh their obligation to give their child the best life possible.

${ }^{49}$ Savulescu, op. cit. note 2, p. 425; Savulescu, op. cit. note 6.

${ }^{50}$ Brock, op. cit. note 8, p. 275.

${ }^{51}$ Bonnie Poitras Tucker. Deaf Culture, Cochlear Implants, and Elective Disability. Hastings Center Report 1998; 28 (4): 6-14.

${ }^{52}$ Savulescu, op. cit. note 2, p. 424.

${ }^{53}$ Brock, op. cit. note 8; Feinberg, op. cit. note 14; Steinbock \& McClamrock, op. cit. note 14.

${ }^{54}$ Buchanan et al., op. cit. note 16, pp.170-6. 